\title{
Research and Analysis on the Influencing Factors of the Purchase Decision of the Consumers of Fast Fashion Goods in Kazakhstan
}

\author{
Sagatdinova Dayana ${ }^{1} \&$ Sha Zhen Quan ${ }^{1}$ \\ ${ }^{1}$ School of Business Administration South China University of Technology, China \\ Correspondence: Sagatdinova Dayana, School of Business Administration South China University of \\ Technology, China. E-mail: sagatdinova.d@mail.ru
}

Received: January 18, 2018

doi:10.5539/ijbm.v13n5p37

\author{
Accepted: March 26, 2018 \\ Online Published: April 6, 2018 \\ URL: https://doi.org/10.5539/ijbm.v13n5p37
}

\begin{abstract}
In the consumer purchase decisions as the starting point, as China and Kazakhstan reached agreement on the implementation of the "Belt and Road" strategy, a large number of fashionable consumer goods in China entered Kazakhstan and enriched the consumer market in Kazakhstan, also changed people's consumption concept in Kazakhstan. In order to obtain a comprehensive and effective research results, the data obtained through the market research were analyzed by using the software of SPSS 20.0 to evaluate the reliability and validity of the data and the fitting degree of the model. Through the confirmatory factor analysis and path analysis of the model, the relationship between the latent variables in the model is obtained, And the results of the investigation and the theoretical analysis are analyzed and studied in detail so as to put forward a positive research proposal to better promote the long-term prosperity of the consumer market of fashion goods in Kazakhstan under the new situation.
\end{abstract}

Keywords: fast fashion, Kazakhstan consumer behavior, consumer purchase decision, structural equation model

\section{Introduction}

In recent years, some successful international fast fashion brands have seized the market in Kazakhstan and expanded rapidly, That exacerbating market competition, and some fashion commodity enterprises in the Kazakhstan are facing tremendous pressure. At the same time, consumers as the main resource of enterprise competition, has become the focus of modern marketing (Mihelis, Grigoroudis, \& Siskos). How to take consumer purchase decision as a starting point and adopt a business strategy that suits the domestic fashion commodity enterprises in Kazakhstan has become a topic of concern for Kazakhstan.

\section{Analysis Of Influencing Factors of Young People's Consumption in Kazakhstan}

\subsection{The Characteristic Factor of Individual}

From the individual level, the individual characteristic factors that affect the decision-making process of fashion goods consumption in young people in Kazakhstan mainly include individual knowledge, individual preference, demographic characteristics and cognitive type.

Firstly: it's individual knowledge;

Secondly: It's individual preferences;

Thirdly: The characteristics of demographic;

Fourthly: Cognitive type.

\subsection{External Stimuli}

External environment and external knowledge are the main factors that influence the decision-making process of young fashion commodity consumption in Kazakhstan.

Firstly, the external environment:

The external environment mainly refers to the services provided by the merchants or service platforms for the consumption of fashion commodities to young people in Kazakhstan in order to assist the young people in Kazakhstan in choosing commodities. 


\section{Secondly, the external knowledge:}

In the process of choosing goods, young people in Kazakhstan need to know the commodity parameters with the help of relevant knowledge of goods. Commodity-related knowledge comes mainly from two aspects, one is the memory of young people in Kazakhstan and the second is the knowledge obtained from the external environment (Cardozo, 2010).

\subsection{Influencing Factors in Post Evaluation Stage}

A complete shopping experience is not without the post-purchase evaluation of young Kazakhs. After receiving the purchased goods, young people in Kazakhstan conduct a comprehensive evaluation on the conformity of goods and merchants, the shopping experience of young people in Kazakhstan, the attitude of merchants, the efficiency and service attitude of logistics companies. At this point, whether the seller can provide the after-sales service that satisfied the young people of Kazakhstan, whether the privacy of the young people in Kazakhstan can be kept confidential will have a certain impact on the post-purchase evaluation. The post-purchase evaluation will to a certain extent affect the subsequent consumption and purchase decisions of other young people in Kazakhstan. To sum up, this paper takes the after-sales service quality and customer information confidentiality as the influencing factors in the post-purchase evaluation process of the young people in Kazakhstan.

\section{Statistical Modeling of SPSS}

\subsection{Sample Selection and Data Analysis}

\subsubsection{Sample Selection}

This paper mainly studies the status quo of the influencing factors on the purchasing decisions of fashionable young people in Kazakhstan. This paper uses a random sampling method to conduct the questionnaire, which is targeted at young people who buy fashion goods in Kazakhstan.

In view of the limitations of the researchers' ability and energy, 350 questionnaires were issued, and the invalid questionnaires were eliminated. The effective questionnaire was 335 , and the recovery rate was $95.71 \%$.

Table 1. Cronbach's Alphaa

\begin{tabular}{ll}
\hline Cronbach's Alpha $^{\mathrm{a}}$ & number \\
\hline .664 & 32 \\
\hline
\end{tabular}

From Table 1 we can see that the coefficient of Cronbach's Alpha is 0.664 , which shows that the survey result is more scientific and the following analysis can be carried out through the questionnaire.

\subsubsection{Descriptive Analysis}

We first summarize the basic information of respondents and process them through descriptive statistics. The results are shown in Table 2 and Table 3.

Table 2. Age

\begin{tabular}{llllll}
\hline & & frequency & percentage & Effective percentage & Cumulative percentage \\
\hline \multirow{4}{*}{ effective } & $15-18$ & 45 & 13.4 & 13.4 & 13.4 \\
& $18-21$ & 108 & 32.2 & 32.2 & 45.7 \\
& $21-24$ & 115 & 34.3 & 34.3 & 80.0 \\
& $24-27$ & 67 & 20.0 & 20.0 & 100.0 \\
\hline
\end{tabular}

From Table 2, we can easily find out that in the respondents, $21-24$ were the most, $115(34.3 \%)$, followed by $18-21,108(32.2 \%)$, and the third was $2427,67(20.0 \%), 15-18$ were the fewest, $45(13.4 \%)$. Therefore, the number of respondents in 18-24 was 182 (54.33\%), while those in 15-18, 24-27, the number of respondents was $153(45.67 \%)$, the ratio between the two: $182: 153=1.190: 1$. Apparently the proportion of respondents is more reasonable. 
Table 3. Gender

\begin{tabular}{llllll}
\hline & & frequency & percentage & Effective percentage & Cumulative percentage \\
\hline \multirow{3}{*}{ effective } & man & 167 & 49.9 & 49.9 & 49.9 \\
& woman & 168 & 50.1 & 50.1 & 100.0 \\
& total & 335 & 100.0 & 100.0 & \\
\hline
\end{tabular}

From Table 3 shows that it is easy to see that there are $167(49.9 \%)$ and $168(168 \%)$ respondents in the questionnaire, accounting for nearly $1: 1$.

\subsubsection{Analysis of Consumer Decision-Making}

\subsubsection{Consumer Decision Factors}

Table 4. Describes statistics

\begin{tabular}{|c|c|c|c|c|c|}
\hline & $\mathrm{N}$ & minimum & $\max$ & mean value & $\begin{array}{l}\text { standard } \\
\text { deviation }\end{array}$ \\
\hline Feeling of love & 335 & 1.00 & 1.80 & 1.2896 & .19479 \\
\hline Easy feeling & 335 & 1.00 & 2.00 & 1.2531 & .19248 \\
\hline Fashion sense & 335 & 1.00 & 2.00 & 1.2615 & .18870 \\
\hline Comparing sense & 335 & 1.00 & 1.80 & 1.2418 & .18094 \\
\hline Pride & 335 & 1.00 & 1.80 & 1.2448 & .18253 \\
\hline No sense of spending power & 335 & 1.00 & 1.80 & 1.2466 & .19995 \\
\hline Effective $\mathrm{N}$ & 335 & & & & \\
\hline
\end{tabular}

From Table 5, we can easily find that there is not a strong Feeling of love (1.2896>1.25) and a slight slight Fashion sense (1.2615> 1.25) for fashion spending, and Easy feeling (1.2531 slightly larger than 1.25) and Pride (1.2448 slightly less than 1.25$)$; however, there is a strong Comparing sense $(1.25>1.2418)$ with no sense of spending power.

3.1.3.2 Mean value score of factors influencing the purchase decision of fashion goods for young people in Kazakhstan

Table 5. Describes Statistics

\begin{tabular}{lllllc}
\hline & $\mathrm{N}$ & minimum & max & mean value & $\begin{array}{c}\text { standard } \\
\text { deviation }\end{array}$ \\
\hline Feeling of love & & & & 1.2813 & .18916 \\
Fashion sense & 182 & 1.00 & 1.80 & 1.2593 & .18920 \\
Easy feeling & 182 & 1.00 & 1.80 & 1.2560 & .18728 \\
No sense of spending power & 182 & 1.00 & 1.80 & 1.2462 & .20934 \\
Comparing sense & 182 & 1.00 & 1.80 & 1.2451 & .18314 \\
Pride & 182 & 1.00 & 1.00 & & .18471 \\
effective N & 182 & & & \\
\hline
\end{tabular}

From Table 5, we can not find out that in the current situation of influencing factors on the purchasing decisions of young fashion merchants in Kazakhstan, there is no strong Feeling of love (1.2813> 1.25), no strong Fashion sense (1.2593>1.25) and Easy feeling (1.2560>1.25), with a slight No sense of spending power $(1.2462<1.25)$, and a very strong Pride $(1.2319<1.25)$. In summary, the intensity of emotions Feeling of love $>$ Pride $>$ Fashion sense $>$ Easy feeling $>$ Comparing sense $>$ No sense of spending power (Kotler \& Zaltman, 1996). 


\subsubsection{Mean Value Score of Consumption Decision Factors}

Table 6. Descriptive statistics

\begin{tabular}{|c|c|c|c|c|c|}
\hline & $\mathrm{N}$ & minimum & $\max$ & mean value & $\begin{array}{l}\text { standard } \\
\text { deviation }\end{array}$ \\
\hline Feeling of love & 153 & 1.00 & 1.80 & 1.2993 & .20147 \\
\hline Fashion sense & 153 & 1.00 & 2.00 & 1.2641 & .18870 \\
\hline Pride & 153 & 1.00 & 1.80 & 1.2601 & .17930 \\
\hline Easy feeling & 153 & 1.00 & 2.00 & 1.2497 & .19905 \\
\hline No sense of spending power & 153 & 1.00 & 1.80 & 1.2471 & .18885 \\
\hline Comparing sense & 153 & 1.00 & 1.80 & 1.2379 & .17881 \\
\hline effective $\mathrm{N}$ & 153 & & & & \\
\hline
\end{tabular}

Table 6 shows that among the 15-18 year olds and 24-27 year olds, the 15-18 year olds and the 24-27 year olds have very low Feeling of love (1.2993> 1.2813) and more Low Fashion sense (1.2641> 1.2593); In addition, there is a lower Pride $(1.2601>1.25)$, Easy feeling $(1.2497=1.25)$ sense of spending power and Comparing sense. In summary, the intensity of emotion (from deviation of mean value) is: Feeling of love $>$ Fashion sense $>$ Comparing sense $>$ Pride $>$ No sense of spending power $>$ Easy feeling (Homburg, Koschate, \& Hoyer, 2006).

\subsubsection{Comparison of the Factors of Consumption Decision}

Through the above statistical analysis found that 18-24-year-old population compared to 15-18 years old, 24-27-year-old population, there is a strong Feeling of love and Fashion sense, when 18-24-year-olds have higher Pride, Easy feeling and No sense of spending power. When there is a lower Comparing sense. Overall, 18-24-year-old population consumption decision-making showed a phenomenon of differentiation, that is, high Feeling of love and high Pride situation, also shows that fashion consumption which have obvious results for different levels of people. On the other hand, the consumption decision-making factors of 15-18 years old and 24-27 years old people treat fashion consumption in a more calm attitude without excessive emotional reaction. Therefore, 18-24 There is a clear difference between the decision-making factors of consumption of the aged population and the consumption decision-making factors of the age group of 15-18 years old and 24-27 years old.

\subsection{Variance Analysis}

3.2.1 Consumer Decision-Making Factors Variance Analysis

Table7. ANOVA

\begin{tabular}{lllllll}
\hline & sum of square & df & Mean square & F & Significance \\
\hline \multirow{2}{*}{ Feeling of love } & $\begin{array}{l}\text { Between } \\
\text { groups }\end{array}$ & .411 & 3 & .137 & 3.700 & .012 \\
& $\mathrm{~s}$ & 12.262 & 331 & .037 & \\
& total & 12.673 & 334 & & \\
\hline
\end{tabular}

Table 8 shows that there is a significant difference in Feeling of love between different age groups $(\mathrm{P}=0.012$ $<0.05$ ). Here we further explore with Multiple comparisons, as shown in Table 8. 
Table 8. Multiple comparisons

\begin{tabular}{|c|c|c|c|c|c|c|c|}
\hline \multirow{2}{*}{$\begin{array}{l}\text { Dependent } \\
\text { variable }\end{array}$} & \multirow{2}{*}{ (I) age } & \multirow[t]{2}{*}{ (J) age } & \multirow[t]{2}{*}{ mean value (I-J) } & \multirow{2}{*}{$\begin{array}{l}\text { Standard } \\
\text { error }\end{array}$} & \multirow[t]{2}{*}{ Significance } & \multicolumn{2}{|c|}{$95 \%$ Confidence interval } \\
\hline & & & & & & Lower limit & Capped \\
\hline & & 2 & -.06519 & .03520 & .343 & -.1600 & .0297 \\
\hline & 1 & 3 & -.05623 & .03484 & .504 & -.1502 & .0377 \\
\hline & & 4 & .02050 & .03517 & .993 & -.0744 & .1154 \\
\hline & & 1 & .06519 & .03520 & .343 & -.0297 & .1600 \\
\hline & 2 & 3 & .00895 & .02690 & 1.000 & -.0625 & .0804 \\
\hline \multirow{7}{*}{$\begin{array}{l}\text { Feeling } \\
\text { love }\end{array}$} & of & 4 & $.08568^{*}$ & .02733 & .012 & .0129 & .1585 \\
\hline & & 1 & .05623 & .03484 & .504 & -.0377 & .1502 \\
\hline & 3 & 2 & -.00895 & .02690 & 1.000 & -.0804 & .0625 \\
\hline & & 4 & $.07673^{*}$ & .02687 & .029 & .0052 & .1483 \\
\hline & & 1 & -.02050 & .03517 & .993 & -.1154 & .0744 \\
\hline & 4 & 2 & $-.08568^{*}$ & .02733 & .012 & -.1585 & -.0129 \\
\hline & & 3 & $-.07673^{*}$ & .02687 & .029 & -.1483 & -.0052 \\
\hline
\end{tabular}

Through Table 9, we can easily find that in the Feeling of love emotion, there is a significant difference between the 4age population and the 6age population, there is a significant difference between the 5age and 6age populations.

Table 9. ANOVA

\begin{tabular}{llllll}
\hline & sum of square & $\mathrm{df}$ & Mean square & $\mathrm{F}$ & Significance \\
\hline Between groups .329 & 3 & .110 & 3.017 & .030 \\
$\mathrm{~s}$ & 12.045 & 331 & .036 & & \\
total & 12.374 & 334 & & & \\
\hline
\end{tabular}

With Table 10, it is not difficult to find that there is a significant difference in Easy feeling among different age fashion consumers $(\mathrm{P}=0.030<0.05)$. The Multiple comparisons are used to further analyze the differences between different ages.

Table 10. Multiple comparisons

\begin{tabular}{|c|c|c|c|c|c|c|}
\hline \multirow[t]{2}{*}{ (I) age } & \multirow[t]{2}{*}{$(\mathrm{J})$ age } & \multirow[t]{2}{*}{ mean value (I-J) } & \multirow[t]{2}{*}{ Standard error } & \multirow[t]{2}{*}{ Significance } & \multicolumn{2}{|c|}{$95 \%$ Confidence interval } \\
\hline & & & & & Lower limit & Capped \\
\hline \multirow{3}{*}{1} & 2 & .09333 & .03583 & .044 & -.0034 & .1901 \\
\hline & 3 & .07208 & .03470 & .225 & -.0219 & .1661 \\
\hline & 4 & .03794 & .04022 & .923 & -.0701 & .1460 \\
\hline \multirow{3}{*}{2} & 1 & -.09333 & .03583 & .044 & -.1901 & .0034 \\
\hline & 3 & -.02126 & .02428 & .944 & -.0857 & .0432 \\
\hline & 4 & -.05539 & .03167 & .404 & -.1400 & .0292 \\
\hline \multirow{3}{*}{3} & 1 & -.07208 & .03470 & .225 & -.1661 & .0219 \\
\hline & 2 & .02126 & .02428 & .944 & -.0432 & .0857 \\
\hline & 4 & -.03413 & .03039 & .841 & -.1155 & .0472 \\
\hline \multirow{3}{*}{4} & 1 & -.03794 & .04022 & .923 & -.1460 & .0701 \\
\hline & 2 & .05539 & .03167 & .404 & -.0292 & .1400 \\
\hline & 3 & .03413 & .03039 & .841 & -.0472 & .1155 \\
\hline
\end{tabular}

As shown in Table 10, we can easily find that, although there is a weak Significance (Significance $0.044<0.05$ ) between 3age and 4age, there is no Significance difference between the other age. 
Table 11. Multiple comparisons

\begin{tabular}{|c|c|c|c|c|c|c|}
\hline \multirow[t]{2}{*}{ (I) age } & \multirow[t]{2}{*}{$(\mathrm{J})$ age } & \multirow[t]{2}{*}{ mean value (I-J) } & \multirow[t]{2}{*}{ Standard error } & \multirow[t]{2}{*}{ Significance } & \multicolumn{2}{|c|}{$95 \%$ Confidence interval } \\
\hline & & & & & Lower limit & Capped \\
\hline \multirow{3}{*}{1} & 2 & -.01519 & .03292 & .998 & -.1038 & .0735 \\
\hline & 3 & -.01101 & .03299 & 1.000 & -.0998 & .0778 \\
\hline & 4 & .00259 & .03441 & 1.000 & -.0900 & .0951 \\
\hline \multirow{3}{*}{2} & 1 & .01519 & .03292 & .998 & -.0735 & .1038 \\
\hline & 3 & .00417 & .02618 & 1.000 & -.0653 & .0737 \\
\hline & 4 & .01777 & .02794 & .989 & -.0567 & .0923 \\
\hline \multirow{3}{*}{3} & 1 & .01101 & .03299 & 1.000 & -.0778 & .0998 \\
\hline & 2 & -.00417 & .02618 & 1.000 & -.0737 & .0653 \\
\hline & 4 & .01360 & .02803 & .997 & -.0611 & .0883 \\
\hline \multirow{3}{*}{4} & 1 & -.00259 & .03441 & 1.000 & -.0951 & .0900 \\
\hline & 2 & -.01777 & .02794 & .989 & -.0923 & .0567 \\
\hline & 3 & -.01360 & .02803 & .997 & -.0883 & .0611 \\
\hline
\end{tabular}

As shown in Table 11, we can easily find that Fashion sense has no significant difference in ageconsumer decision-making factors.

Table 12. Multiple comparisons

\begin{tabular}{|c|c|c|c|c|c|c|}
\hline \multirow[t]{2}{*}{ (I) age } & \multirow[t]{2}{*}{ (J) age } & \multirow[t]{2}{*}{ mean value (I-J) } & \multirow[t]{2}{*}{ Standard error } & \multirow[t]{2}{*}{ Significance } & \multicolumn{2}{|c|}{$95 \%$ Confidence interval } \\
\hline & & & & & Lower limit & Capped \\
\hline \multirow{3}{*}{1} & 2 & -.03481 & .02885 & .792 & -.1122 & .0426 \\
\hline & 3 & -.03188 & .02840 & .841 & -.1081 & .0443 \\
\hline & 4 & -.03144 & .03112 & .896 & -.1149 & .0520 \\
\hline \multirow{3}{*}{2} & 1 & .03481 & .02885 & .792 & -.0426 & .1122 \\
\hline & 3 & .00293 & .02524 & 1.000 & -.0641 & .0699 \\
\hline & 4 & .00337 & .02826 & 1.000 & -.0720 & .0787 \\
\hline \multirow{3}{*}{3} & 1 & .03188 & .02840 & .841 & -.0443 & .1081 \\
\hline & 2 & -.00293 & .02524 & 1.000 & -.0699 & .0641 \\
\hline & 4 & .00044 & .02780 & 1.000 & -.0737 & .0746 \\
\hline \multirow{3}{*}{4} & 1 & .03144 & .03112 & .896 & -.0520 & .1149 \\
\hline & 2 & -.00337 & .02826 & 1.000 & -.0787 & .0720 \\
\hline & 3 & -.00044 & .02780 & 1.000 & -.0746 & .0737 \\
\hline
\end{tabular}

As shown in Table 12, it is not hard to find Comparing sense has no significant difference in age consumer decision-making factors.

Table 15. ANOVA

\begin{tabular}{llllll}
\hline & sum of square & df & Mean square & F & Significance \\
\hline \multicolumn{2}{l}{ Between groups .156} & 3 & .052 & 1.571 & .196 \\
$\mathrm{~s}$ & 10.972 & 331 & .033 & & \\
total & 11.128 & 334 & & & \\
\hline
\end{tabular}

As shown in Table16 and Table17, we can easily find that there is no significant difference in Pride sense between different age consumer decision-making factors. 
Table 16. Multiple comparisons

\begin{tabular}{|c|c|c|c|c|c|c|}
\hline \multirow[t]{2}{*}{ (I) age } & \multirow[t]{2}{*}{$(\mathrm{J})$ age } & \multirow[t]{2}{*}{ mean value (I-J) } & \multirow[t]{2}{*}{ Standard error } & \multirow[t]{2}{*}{ Significance } & \multicolumn{2}{|c|}{$95 \%$ Confidence interval } \\
\hline & & & & & Lower limit & Capped \\
\hline \multirow{3}{*}{1} & 2 & .01556 & .03312 & .998 & -.0739 & .1050 \\
\hline & 3 & .05546 & .03329 & .468 & -.0344 & .1453 \\
\hline & 4 & .01141 & .03635 & 1.000 & -.0863 & .1091 \\
\hline \multirow{3}{*}{2} & 1 & -.01556 & .03312 & .998 & -.1050 & .0739 \\
\hline & 3 & .03990 & .02401 & .461 & -.0238 & .1036 \\
\hline & 4 & -.00415 & .02810 & 1.000 & -.0792 & .0709 \\
\hline \multirow{3}{*}{3} & 1 & -.05546 & .03329 & .468 & -.1453 & .0344 \\
\hline & 2 & -.03990 & .02401 & .461 & -.1036 & .0238 \\
\hline & 4 & -.04405 & .02830 & .541 & -.1196 & .0315 \\
\hline \multirow{3}{*}{4} & 1 & -.01141 & .03635 & 1.000 & -.1091 & .0863 \\
\hline & 2 & .00415 & .02810 & 1.000 & -.0709 & .0792 \\
\hline & 3 & .04405 & .02830 & .541 & -.0315 & .1196 \\
\hline
\end{tabular}

Table 17. Multiple comparisons

\begin{tabular}{lllllll}
\hline (I) age & (J) age & \multicolumn{2}{c}{ mean value (I-J) } & Standard error & Significance & \multicolumn{2}{c}{$\begin{array}{l}95 \% \text { Confidence interval } \\
\text { Lower limit }\end{array}$} & Capped \\
\hline \multirow{3}{*}{1} & & & & .0625 & .1307 \\
& 2 & .03407 & .03570 & .920 & -.0830 & .1174 \\
& 3 & .01720 & .03716 & .998 & .0681 & .1447 \\
& 4 & .03828 & .03957 & .914 & .0625 \\
& 1 & -.03407 & .03570 & .920 & -.1307 & .0535 \\
& 3 & -.01688 & .02652 & .989 & -.0873 & .0838 \\
& 4 & .00420 & .02981 & 1.000 & -.0754 & .0830 \\
& 4 & -.01720 & .03716 & .998 & -.1174 & .0873 \\
& 1 & .01688 & .02652 & .989 & -.0535 & .1052 \\
& 2 & .02108 & .03153 & .985 & -.0630 & .0681 \\
& 4 & -.03828 & .03957 & .914 & -.1447 & .0754 \\
& 1 & -.00420 & .02981 & 1.000 & -.0838 & .0630 \\
\hline
\end{tabular}

As shown in Table18 and Table19, we can easily find that No sense of spending power has no significant difference in different age Consumer decision-making factors.

In summary, only Feeling of love and Easy feeling are different in age Consumer decision-making factors among the six kinds of emotions. In the Feeling of love emotion, the ratio of 4age in 15-18 years old and 24-27 years old group 6age of 18-24-year-olds have a lower Feeling of love, and 5age of Feeling of love is lower in 5 -year-olds than in 18-year-olds. In Easy feeling, only 15-18, there is a difference between the ages of 24 and 27 when 4age has a higher Easy feeling than 3age.

\subsubsection{Gender Differences Is Analysed}

We have analyzed the differences in the mood of different sentiments between the ages of 15-18 and the ages of 24-27, and found that the influencing factors of decision-making of fashionable young people in Kazakhstan are related to those of 15-18 years old and 24-27 years old. There is a significant difference between Feeling of love and Easy feeling, but there is no significant difference among the other four kinds of emotions. Nowadays, we analyze the sex difference of influencing factors on the decision-making of young fashion in Kazakhstan. 
Table 18. Group statistics group statistics

\begin{tabular}{|c|c|c|c|c|c|}
\hline & $\operatorname{sex}$ & $\mathrm{N}$ & mean value & standard deviation & mean value Standard error \\
\hline \multirow{2}{*}{ Feeling of love } & $\operatorname{man}$ & 100 & 1.2020 & .16936 & .01694 \\
\hline & woman & 82 & 1.3780 & .16631 & .01837 \\
\hline \multirow{2}{*}{ Easy feeling } & $\operatorname{man}$ & 100 & 1.2540 & .18825 & .01883 \\
\hline & woman & 82 & 1.2585 & .18722 & .02067 \\
\hline \multirow{2}{*}{ Fashion sense } & $\operatorname{man}$ & 100 & 1.2460 & .19869 & .01987 \\
\hline & woman & 82 & 1.2756 & .17678 & .01952 \\
\hline \multirow{2}{*}{ Comparing sense } & $\operatorname{man}$ & 100 & 1.2600 & .18749 & .01875 \\
\hline & Woman & 82 & 1.2268 & .17712 & .01956 \\
\hline \multirow{2}{*}{ Pride } & $\operatorname{man}$ & 100 & 1.2140 & .16393 & .01639 \\
\hline & woman & 82 & 1.2537 & .20620 & .02277 \\
\hline No sense of & fman & 100 & 1.2580 & .21704 & .02170 \\
\hline \multicolumn{2}{|c|}{ spending power woman } & 82 & 1.2317 & .19992 & .02208 \\
\hline
\end{tabular}

With Table 18, we find it very hard to find significant differences in the 6 sentiments between men and women, and for this we conducted an analysis by means of independence test, the result of which is shown in Table 18.

Table 19. Test of mean value equation

\begin{tabular}{llllll}
\hline & \multicolumn{2}{l}{ T test of mean value equation } & & & \\
\cline { 2 - 5 } & $\mathrm{t}$ & $\mathrm{df}$ & $\mathrm{S}$ mean value & Standard error \\
\hline Feeling of love & -7.034 & 180 & .000 & -.17605 & .02503 \\
Easy feeling & -.162 & 180 & .871 & -.00454 & .02798 \\
Fashion sense & -1.051 & 180 & .295 & -.02961 & .02818 \\
Comparing sense & 1.217 & 180 & .225 & .03317 & .02725 \\
Pride & -1.446 & 180 & .049 & -.03966 & .02744 \\
No sense of spending power .842 & 180 & .401 & .02629 & .03121 \\
\hline
\end{tabular}

With Table 18, it is not difficult to find that there is a significant difference (Sig. $=0.000)$ between Feeling of love and Pride between men and women in Kazakhstan who influence the purchasing decisions of fashion merchandise, while other sentiments are not significantly different between men and women.

In summary, part of the sentiment in the influence factors of young people's fashion purchasing decisions in Kazakhstan is significantly different in gender.

\subsection{Establishment of Model}

\subsubsection{Regression analysis-Regression Generating Model}

According to previous research scholars to make purchase decision-making model to improve the method, together with the author's own understanding of the model made the following analysis:

A linear regression equation (Yin, 2012):

$$
y=\alpha+\beta x
$$

$\mathrm{y}$-Predictors of influencing factors; $\mathrm{x}$ - Influencing factors of purchasing decision;

$$
\left\{\begin{array}{l}
\frac{\partial Q}{\partial \alpha}=2 \sum_{i=1}^{n}\left(\alpha+\beta x_{i}-y_{i}\right)=0 \\
\frac{\partial Q}{\partial \alpha}=2 \sum_{i=1}^{n}\left(\alpha+\beta x_{i}-y_{i}\right) x_{i}=0
\end{array}\right.
$$

$\alpha \_$Regression constants; $\beta \_$Regression coefficients; 


$$
\alpha=\frac{1}{n} \sum_{i=1}^{n} y_{i}-\frac{\beta}{n} \sum_{i=1}^{n} x_{i}
$$

Least square method: to meet $Q=\sum_{i=1}^{n}\left(\alpha+\beta x_{i}-y_{i}\right)^{2}$ Min.

$$
\begin{aligned}
& \sum_{i=1}^{n}\left(\frac{1}{n} \sum_{i=1}^{n} y_{i}-\frac{\beta}{n} \sum_{i=1}^{n} x_{i}+\beta x_{i}-y_{i}\right) x_{i}=0 \\
& \sum_{i=1}^{n}\left(\frac{1}{n} x_{i} \sum_{i=1}^{n} y_{i}-\frac{\beta}{n} x_{i} \sum_{i=1}^{n} x_{i}+\beta x_{i}^{2}-x_{i} y_{i}\right)=0 \\
& \frac{1}{n} \sum_{i=1}^{n} x_{i} \sum_{i=1}^{n} y_{i}-\frac{\beta}{n} \sum_{i=1}^{n} x_{i} \sum_{i=1}^{n} x_{i}+\beta \sum_{i=1}^{n} x_{i}^{2}-\sum_{i=1}^{n} x_{i} y_{i}=0
\end{aligned}
$$

multivariable regression: $y=\alpha+\beta_{1} x_{1}+\beta_{2} x_{2}+\cdots+\beta_{n} x_{n}$

Through the author's own knowledge of A linear regression equation and multiple regression, the author studies the co $\beta$ mplicated data preprocessing involving multiple regression, the data processing and the multiple regression on the influencing factors of young people's fashion purchasing decision in the later model prediction There will be detailed instructions.

According to the investigation of some relevant data about the influencing factors of young people's fashion purchasing decisions, the cross-classification method is used to analyze the factors influencing the purchasing decisions of young fashion products in Kazakhstan. According to the Feeling of love, Fashion sense, Vanity Sense, and then according to different factors to analyze and determine the impact of the cross-cutting rate. Due to not processing the survey data, but directly to use, so it reflects the actual situation of Kazakh youth fashion product purchase decision-making factors.

\subsubsection{General Linear Model}

This is the earliest model developed in the functional model, which implies that the various factors that affect the purchase decision-making method are expressed in the form of linear functions to estimate the share of the purchase decision-making method. However, the sharing rate $\mathrm{Pi}$ Can not be guaranteed $0<\mathrm{P}_{\mathrm{i}}<1$.

The odds of some kind of purchasing decision-making among OD pairs can be expressed as:

$$
p_{i}=\frac{\exp \left(V_{i}\right)}{\sum_{i=1}^{K} \exp \left(V_{i}\right)}
$$

In General linear model, Satisfy:

$$
\frac{0 \leq P_{i} \leq 1}{\sum P_{i}=1}
$$

In this model, the parameters are scaled by the results of a persennal purchase decision survey.

This model fits for the situation where there are only two kinds of purchasing decisions and the probability that the purchasing decision is chosen is given by:

$$
P_{i}=\frac{1}{2 \pi} \int_{-\infty}^{Y_{i}} \exp \left(-2 / t^{2}\right) d t
$$

$Y_{i}$ : Table shows the difference between the linear function values of the two purchase decisions.

General linear model in today's urban decision making decision-making is very wide range of applications, the basic direction of this model and other models have a big gap in the partition is that this model will buy decision-making choices into free and non-free choice These two, very accurate grasp of the choice of people when buying psychology, the advantage of the two purchase decision-making characteristics can be used even if not independent (Zeithaml, 1988). 


\subsection{Analytic Result}

Fast fashion brand has a significant impact on the purchase behavior, and it has a direct positive impact and an indirect negative influence. It shows that the most important mechanism that the fast fashion brand affects consumers' buying behavior is direct action, indirect action is achieved through three ways, But neither significant nor negative impact. The fashion environment also has a direct and indirect impact on the purchase behavior, the impact coefficient is small, we can see the fashion environment on the purchase behavior of consumers is not significant. This also shows that the fast fashion brand has Broad space for development.

\section{Conclusion}

Therefore, one of the characteristics of Kazakhstan's fast fashion brand is the implementation of "fast follow" marketing strategy, rather than trying to be "trend creators." Its target consumers are trend followers, with the rise of consumer fashion, This group tends to interpret fashion as a personality, the pursuit of the uniqueness of the performance of self, so fast fashion brand in the operation of adding more original and unique products in order to better attract consumers in Kazakhstan.

\section{References}

Cardozo, R. N. (n.d.). An Experimental Study of Customer Effort, Expectation, and Satisfaction. Journal of Marketing.

Homburg, C., Koschate, N., \& Hoyer, W. D. (2006). The Role of Cognition and Affect in the Formation of Customer Satisfaction: A Dynamic Perspective. Journal of Marketing, 70(3), 21-31. https://doi.org/10.1509/jmkg.70.3.21

Kotler, P., \& Zaltman, G. (1996). Social marketing: An approach to planned social change. Journal of Marketing, $35(3-4), 7-20$.

Mihelis, G., Grigoroudis, E, \& Siskos, Y. (2001). Customer satisfaction measurement in the private bank sector. European Journal of Operational Research, 130(2), 347-360. https://doi.org/10.1016/S0377-2217(00)00036-9

Yin. F. (1994). Research of consumer behavior under the environment of electronic commerce. Electronic Design Engineering, 4, 31-33.

Zeithaml V A. (1988). Communication and Control Processes in the Delivery of Service Quality. Journal of Marketing, 52(2), 35-48. https://doi.org/10.2307/1251263

\section{Copyrights}

Copyright for this article is retained by the author(s), with first publication rights granted to the journal.

This is an open-access article distributed under the terms and conditions of the Creative Commons Attribution license (http://creativecommons.org/licenses/by/4.0/). 